\title{
Legal Renewal of Cash Waqf Law Through Legal System Approach
}

\author{
Islamiyati $^{1}$, Rofah Setyowati ${ }^{2}$, Dewi Hendrawati ${ }^{3}$, Ahmad rofiq ${ }^{4}$ \\ $\left\{\right.$ islamiyati@yahoo.co.id ${ }^{1}$,rofah_undip@yahoo.com ${ }^{2}$,dewi.hendrawati56@gmail.com ${ }^{3}$, \\ ahmadrofiq@gmail.com ${ }^{4}$ \} \\ ${ }^{1,2,3}$ Faculty of Law Diponegoro University, Prof. Sudharto, SH. Street Number 1 Semarang, Indonesia \\ ${ }^{4}$ State Islamic University Walisongo Semarang, Indonesia
}

\begin{abstract}
The disharmony between the rule of law and the practice money waqf is reason for the renewal of waqf law. The research analyzes the reasons why the renewal money waqf law must be carried out and how the concept of the approach to legal system theory. The benefits can government in implementing the waqf money law policy. Research includes socio-legal research, the empirical juridical approach method. The results showed that the reasons for the renewal of money waqf law were; misunderstanding in money waqf, lack of coordination among money waqf institutions, and the legality of money waqf in LKS-PWU is doubtful. Renewal of waqf money according to the legal system theory approach; legal structure was conduct an open access strategy LKS-PWU. Legal substantion was rules a bout position of the LKS-PWU as nadzir and perfected for the waqf application. Legal culture was socialization of waqf money law in the community.
\end{abstract}

Keywords: Legal Renewal, Cash Waqf, Legal System Theori.

\section{Introduction}

The waqf law in Indonesia always develops along the development of moslems in doing the religious teaching, including the idea of cash waqf enactment. The goverment has established the enactment of cash waqf law through fatwa MUI in May, $11^{\text {th }} 2002$ in order to fulfill the need of law hence the society will understand that cash waqf is allowed. The reasons are the benefits of waqf are very helpful for the goverment in the effort of poverty alleviation, welfare improvement, and the health.[1] The determination of cash waqf enactment become the legal solution of the debate whether cash waqf is allowed or not in Indonesia.

Cash waqf becomes a new trend in the charitable deeds. In the former, the people should wait until they have land and build the building on it. Now, people can do waqf everytime they can. They can give money as a waqf and nadzir will manage it until it becomes waqf asset and be useful for the society. Money waqf (cash waqf) is one waqf that is practiced by the moslem people in Indonesia after the Rules of waqf No. 41/2004 in October, $27^{\text {th }} 2004$ is determined.

Cash waqf is one renewal of waqf law in Indonesia. It is adopted from Malaysia and Bangladesh which permitt cash waqf to build the company, mall, or public facility. The benefits of them is used to help the society in order to be apart from the poverty. [2] Cash waqf has two roles, namely it roles as the worship in the form of jariyah charity and the 
social charity (ijtima'iyyah worship) because the benefits can be felt directly by the public. If the treasure of money can be managed well and rightly, it can be used as one solution to solve the economy crissis, to improve the prosperity and become source of capital for the community empowerment.[3]

The goverment established he rules of cash waqf after analizing the potency of waqf treasure in Indonesia which in the future it is predicted can help the goverment in order to implement the objective of national development. There are two cash waqf laws that are applied in the society. First, the rules that based on the religioue rules and the values in $\mathrm{Al}$ Quran and Al-Hadist and also Fiqh bible from the scholars of moslem law experts. Second, the law that is existed in the rules stated by the goverment, The Waqf Rules, Goverment Rule No. 42/2006 about The Rules of Waqf Implementation, PBWI No. 1/2009 about the Guidance of management and development of Movable Waqf Treasure in the form of money, PBWI No. 2/2009 about The Guidance of Receiving Cash Waqf for Nadzir of BWI.

Ideally, law of cash waqf above can be implemented by the society because basically the law comes from religious values and from the nation values in which there are no contradiction betweem them. The national law sets more detail in order to be practiced in the society. Besides, the national law has a goal to give the certainty and the protection law for wakifs therefore their charity will be appropriate with their objectives and benefits. [4] Unfortunately, the reality of cash waqf implementation is different from its goal. There are still some issues that cause the law problematics in the society. According to the research done by Aam S, Rusdiana and Abrista Devi (2017), it explains that the problems which come up in developing cash waqf include the belief of wakiq to LKS-PWU, human resources, system, and syariah aspect. The solution offered is by giving a training about understanding and managing of cash waqf, and also the service of cash waqf in the society by the institutions of cash waqf.[5]

Based on the research done by Suhairi (2011) about Pengelolaan Wakaf Uang(Studi terhadap implementasi Wakaf Uang di Baitulmaal Muamalat) it explains that the management of cash waqf in BMM, as PKS-BWU is not wholly suitable with the rule of practicing cash waqf. It shows that the pledge and the certificate of cash waqf have not been suitable with the rules and the investment of cash waqf. It is not optimal. That research also describes a problem in relation to practicing cash waqf in BMM therefore the investment of cash waqf has not been maximum. It is caused by the condition that the society tend to do waqf directly and individually to nadzir.[6]

Those law problems effect to the enforcement of law in relation to cash waqf. It makes practicing of cash waqf inappropriate with the existing cash waqf rules. Furthermore the principles of waqf and the aspects of waqf can not be fullfiled. Besides, the society culture of doing waqf become low because the factor of mistrust to waqf institution. If the situation is being ignored, the problems of cash waqf law will effect the juridical to the law that can not be enforced in the society since there are misappropriation and violation to the objective of waqf rule. As a result it does not give the value of justice in the society.

Based on the previous explanation, there is a legal issues between the cash waqf rule existed in the legislation and the realization in the society. The practice of cash waqf has been managed in the rule of legislation (das sollen), unfortunately in fact there is still a law problem in practicing cash waqf in the society (das sein) from the culture law point of view. For that reason, the research about the renewal of legal culture of cash waqf through legal system is important to be done. The research will analyze the reasons why the renewel law of cash waqf practice through legal system theory approach must be done and how is the concept of its approach used? 
The objective of the research is to analyze the reasons why the renewel law of cash waqf practice through legal system approach must be done and how is the concept of its approach used. The benefit is that the research can give an idea for the goverment in implementing policy about the renewal of cash waqf law as a solution of the cash waqf law problem in Indonesia. Moreover, the research is important to be done as an effort in implementing the enforcement of waqf law which is based on Pancasila.

\section{The Research Method}

This research is a socio-legal research which analyzes the problems of cash waqf law in the society and its renewel law therefore the endowment of cash waqf can be implemented fairly. It is suitable with the legal need in the society. This research is a qualitatif research with a goal to build a theory concept that is based on the data and the research source. The approach method uses empirical juridical. Juridical means that the research try to search many things corelated to the law formally or informally. Empirical means that the research is about the implementation of cash waqf law in the society, the relation between law and the society, and how is the legal problem and the legal renewal of cash waqf.

The data of the research needed is the primary and secondary data. The primary data comes from the research object namely Central Java. The sample of the research includes Semarang Regency and Semarang City, Salatiga and Boyolali Regency. The primary data is obtained through interview from the specific speaker. Whereas the secondary data is obtained through the library study and documentation. The secondary data consists of primary, secondary and tertiary law materials. The data of the research will be analyzed using descriptive analysis where the research result will be described, and then it is analyzed in order to answer the research problem. The data processing is done by examining, organizing, concepptualizing, or compiling data, synthesizing, analyzing, editing, coding and concluding, therefore the objectives and the benefits of the research will be reached.

\section{Discussion}

\subsection{The Reasons of The Legal Renewal of Cash Waqf}

Cash waqf is a waqf deed in order to divert the benefits of cash waqf treasure, from individual owner into social one that is based on Islamic syariah. The law of cash waqf is the rule used as the guidance in the implementation of cash waqf in the society. The people often do cash waqf using existing rule or the principle that are often practiced in social life, by imitating waqf law with zakat, infaq and shadaqah. In contrast, actually, the goverment has managed the practice of cash waqf, such as in article 28,29 and 30 of Waqf Rule, Article 22 up tp 27 PP No. 42/2006, PBWI No. I/2009 and PBWI No 2/2009. Hence there is a disharmony between the law of cash waqf that has been stated in the rule with the realization of cash waqf implementation in the society. That legal disharmony causes some problems of cash waqf law . In this paper, the reasons of legal renewal of cash waqf using legal system theory will be explained.

The discussion about the reason of legal renewal of cash waqf through legal system theory approach will be answered if the cause of that renewal is being explained first. The reason of legal renewal of cash waqf is the condition that there is still some problems in implementing cash wafq in the society. The law problems are as the following;

1. Misunderstanding of cash waqf in the society. There are two misunderstanding of cash waqf. First, cash waqf is defined as a waqf in the form of cash that is spent in 
the form of things based on wakif's order by Nadzir. The people give their waqf does not to LKS-PWU but they give it directly to nadzir. People interpret that money waqf is the same with cash waqf, because wakif spends some money when they do waqf. However, according to the rule, waqf should be done in front of LKS-PWU. Second, cash waqf is the same with infaq, shadaqah and zakat. The people who give their treasure often focus on their religious deeds on infaq, since they think that infaq is the same with waqf because it is jariyah deeds. In fact, infaq and waqf is different in its pledge, in its eternity benefits of waqf treasure, in the objective of its benefit and its jariyah deeds. If it is in the form of things or materials, they direct their religious deeds by alms. The society believe that waqf should be in the form of giving material or things in the form of permanent asset/land, therefore it need much treasure. For that reason, the implementation of cash waqf as stated by the rules has not been practiced yet.

2. The interest of people to do waqf is very low. It is because the people think that waqf treasure is a permanent asset in the form of land in order to build the mosque, education building, pondok pesantren, cemetery, hospital, and hall. If it is in the form of cash, the cash waqf from the people is used to build religion's facility and its equipments, for example: for buying carpet, mat, speaker, dome, etc. Besides, the society is more interested to land waqf because it has real form and benefit. Moreover wakif can use its function. If they have some money, they are more familiar with infaq, shadaqah and zakat.

3. The problems of cash waqf law which is happened in LKS-PWU is that the waqf law subject (wakif) does not give cash waqf in LKS-PWU for there is no socialization how to do cash waqf in the society. As a result the society does not know about the goverment program in relation to cash waqf done by LKS-PWU. Moreover, the society has not believe that LKS-PWU as a service for doing cash waqf so that they tend to believe in managing waqf treasure directly to nadzir. The system of storage in LKS-PWU is still debatable because the donation is saved in the bank where it is surely should pay for the tax or administration fee. In the contrary the waqf treasure must not be spent. This condition makes some institution of LKS-PWU do not receive cash waqf. They suggest people to do zakat or infaq.[7] The above reasons cause the implementation of cash waqf in LKS-PWU running unwell. It concludes, cash waqf which is stated in the rules can not be practized in the society.

4. Political will about cash waqf.

The goverment will in giving budget facility has not been implemented to socialize cash waqf in the society completely. That budget is only enough to the empowerment of nadzir. This condition causes the instituion of cash waqf, like BWI can not work maximally, moreover BWI makes it as odd jobs. The goverment here is meant as the ministry of finance which arrange the national budget under the president agregement. The Ministry of religion has a job to give service for waqf in the society including BWI.

5. Less coordination among the institution of cash waqf

Cash waqf is waqf in the form of money done in the front of LKS-PWU. The manner of cash waqf is as follows. Firstly, wakif comes to LKS-PWU to do cash waqf. And then wakif fills the form and signs deposit form of cash waqf. Money is received by the bank and it gives that form as a waqf deed pledge. After that LKS-PWU deposits it in BWI to be administered and gives cash waqf to nadzir who cooperate with LKSPWU. However, among those previous cooperation parts (LKS-PWU, BWI, Nadzir), 
there is no harmonious relation. As a result the society does not understand about the procedure of cash waqf. LKS-PWU does not cooperate with BWI and vice versa. BWI never receives the report from LKS-PWU, whereas nadzir manages the waqf treasure individually from the society. There are LKS-PWU and BWI as the institution components of law enforcement in cash waqf practice. Unfortunately there is no good coordination between them in the enforcement of waqf law.

6. The legality of cash waqf

The goverment set the law of cash waqf in order to help the society in practicing waqf easily without leaving its pillars and requirements. Therefore their action have a legality. Unfortunately, in the reality, in practicing cash waqf in LKS-PWU, there are still transactions that do not fulfill the pillars and the requirements. In the form of submission proof form, there is no place for giving signature from witness and nadzir although both of them are waqf pillars. For that reason the implementation of cash waqf does not fulfill the pillars or the requirements as stated by waqf regulations.

Based on the previous explanation, it can be concluded that the reason of the renewal of cash waqf law is because of the disharmony condition between cash waqf law and the practice of cash waqf in the society. The rule of cash waqf stated in the Article 28, 29, 30 of waqf Rules, Article 22 up to 27 No. 42/2006, PBWI No. I/2009, and PBWI No. 2/2009 are not effective in the society. There is an understanding that the rule of the right waqf must use those appropriate with the fiqh teaching determined by madzab imam. It causes the problem of cash waqf law in the society, such as; misunderstanding about cash waqf that make the interest of the people low to do waqf, there is less communication among waqf institutions, the legality of cash waqf is not fulfilled in LKS-PWU, less attention from the goverment in socializing cash waqf to the society.

\subsection{The Renewal of cash waqf law through the Theory of Legal System in Indonesia}

Based on previous discussion, the renewal law of cash waqf is very important to be done. It is the process of checking the existing cash waqf law, the process of advocating and also implementing the changes in the law system, making the efficiecy of law. Therefore the law can be implemented in the society. The renewal of the law is bagun by critizicing existing rules or the law. After that the implementation in the society is checked. If it is not efficient or can not be enforced, therefore the law can be renewed.[8]

The renewal of law is oriented to the fair law enforcement, from the aspect of law substancy (legislative/the rules of cash waqf), Structural aspect (judicatifl the waqf law enforcer) and the culture aspect (law culture of the society).[8] The benefits of cash waqf renewal is to make cash waqf more effective and it can be implemented in the society. Furthermore it can support the goverment effort in determining national policy in order to reach the objectives of national development.

The legal renewal of cash waqf is the renewal of law system in order to enforce the justice. By using the theory of legal system from Lawrence M. Friedmen, it can be used as the approach method in law renewal of cash waqf. The Theory of legal system stated by Lawrence M. Friedmen explains that the law is one unity system which consist of three components, such as; law structure (legal structure), substantion law (legal substantion) and culture law (legal culture),[9] each will be explained as the following; [10] 
1. Legal structure, means the law enforcement that is done by the institution made by law system. It consists of jugde, court jurisdiction, clerk, that give the service and cultivation of law regularly. The enforcement of law is influenced by the court institution whose the power and right to finish and solve legal dispute.

2. Legal Substantion, means the enforcement of law that comes from a lot of rules and provisions of how that law must be done. The legal substantion consist of the rules materials that are used as guidances or bases for the law enforcers. There are two law rules, such as primary rule called material rule and the secondary rule called formal rule. The law substantion is thought as the one part of the body that is called the strong and upright body skeleton. It is hard and rigid bone which keep the body so that the blood circulation run well within its limit.[10]

3. Legal culture, means the enforcement of law comes from legal component in the form of idea, attitude, hope and opinion about the law from the society. This components come from the social power in order to enforce the law. It means that the power of cultufre and social habit become one important aspect in implementing the rule. Culture or culture law is definitely different between one and another, because the law is always limited by the surrounding environment and situation. It makes the level of legal compliance in teh society is influenced by the characteristic of the society. [11]

If the above systems can be done harmoniously, therefore the law can be functioned positively or it can make a benefits to human being. As a result the law can manage the life of human being more regularly. If the law theory of legal system used as the approach method to renewal the law of cash waqf, the explanation is as the following;

1. The renewal of legal structure. It is the law renewal of cash waqf showed by the choosen institutions to give service for the society, such as; LKS-PWU, nadzir and BWI. LKS-PWU needs to open access strategy in giving waqf service in the society, and also it should build the belief of the people to be aware of doing cash waqf through LKS-PWU. Besides, it also forms professional BWI with integrated management in holding the treasure of cash waqf. Moreover it also should build integrated coordination and cooperation between BWI and LKS-PWU and also nadzir in Indonesia. It is hoped that the society awareness will be improved in doing cash waqf and people believe to the institutions of cash waqf. Hence the law of cash waqf can be enforced and the treasure of cash waqf can be managed well and profesionally so that the benefits can be used as the prosperity of the people.

2. The renewal of legal substantion. It is the renewal of law from the aspects of its rules and its law certainty, for example: the law which explain that LKS-PWU does not only receive the donation of waqf from the society, but also it is choosen as a nadzir management of cash waqf. The reason is that LKS-PWU is as syariah financial institution which is expert in managing financial based on syariah, including cash waqf. Besides, there should be a legal rule that ensure the legalcy of cash waqf. In this case LKS-PWU should complete the application form of cash waqf in which there is a signature column for witness and nadzir as an important aspect in cash waqf.

3. The renewal of legal culture. It is the renewal of waqf law from the aspect of legal cultufre or the habitual action in the society. The legal culture has components of values, attitude, belief, wisdom of sight, opinion, and habit which become supporting factors to receive the rules of cash waqf law or refuse it. The culture habit can move 
people/individu to be obedient or inobedient to the existing law system.[12] The law renewal from this aspect is for example; the socialization of legal rule in cash waqf, legal education about cash waqf,seminar, workshop, training and the endowment of law in implementing cash waqf in the society. That activity can be applied in the society, academy, practition and stackholder of cash waqf.

The goal of law renewal of cash waqf is to easy the implementation of the law in the society and to avoid the disharmony between the law set by the nation with the law based on the religious principles. The goverment establishes the law of cash waqf so that all the involved parties will get the certainty and protection of law so that there is no legal dispute in the future. The goverment law does not contradict with the religion law. The goverment want to create the orderly law and the good management in implementation and management of cash waqf. Unfortunately, the society still uses the old culture that practice the cash money by using old paradigm. They do cash waqf in the ly given tradisional scale, take for example the cash waqf is direct to nadzir and not to LKS-PWU. Besides, there is no coordination between BWI, LKS-PWU and nadzir. As a result controlling and evaluating of cash waqf development is difficult to be done. Wakif understand that waqf is only in the form of land. If they do cash waqf, it is used to buy land in order to implement the waqf treasure.

Knowing this phenomena, the goverment should make hard effort to instill the understanding to the society and to apply cash waqf rule. Furthermore, There are some facilities in implementing cash waqf such as the profesional and trusted institutions which has a duty to service the people in order to do cash waqf. It is hoped that the institution will service the people hence they will be easy to do cash waqf. This effort is aimed to change the society to be obedient to the law determined by the goverment and also be obedient to the religious institutions as well.

The law is aimed to change the people obedient to the rules. Since the relation between the law and the sociecy will effect each other, the law can change and reconstruct the society. In this case, the law becomes the solution to change the society. Jeremy Bentham believes that the law can be reconstructed rationally and it can play the role in reforming the society, $[13]$ in other words the society should be changed. Their way of thinking have to be changed in understanding the existing law. Finally It can be decided that it is not the law to be changed. In relation to the law of cash waqf, basically the goverment does not change the basic rules of cash waqf law because the basic rules of cash waqf law has been practiced by Nabi Muhammad as the bearer of the treatise from the Lord. The goverment only improve or complete the manner of implementing and managing cash waqf so that its benefits can be felt by the people. For that reason, the empowerment of law and the socialization law of cash waqf are very needed hence the society will understand the manner and the management of cash waqf. It means that the cooperation among some parties are very important, such as ; Religion Ministry, BWI, PPAIW, the society's leader as well as the religion's leader. (scholars and crerics). It is hoped that there is the non-uniformity of understanding about cash waqf and avoid misunderstanding of it in the society.

The renewal of cash waqf law is needed to build national legal order which ensure the certainty and protection of law. Mochtar Kusumaatmaja has created about national law development. He conceptualizes that the law does not only manage the principles and basics which rule the social life, it also includes the institutions and some processes to implement the law principle in the reality.[14] So Mochtar Kusuma Atmaja views that the law is the unity system that consist of subsystems, namely; the principles and rules of law, law institutions and the process of law implementation.[15] For that reason, the law should be fostered in order to 
be enforced and implemented in the society. The national legal development must be aimed to the planned efforts in order to:

1. Improve the rules of law by adjusting them with the development of era without ignoring the awarness of law in teh society.

2. Bring order the law institution so that it is suitable with its rights.

3. Improve the ability and the authority of the law enforcer.

4. Adjust the awareness of law in the society and adjust the behaviour of the goverment officials to the law enforcement, the justice and the protection to the human being dignity, the legal order and the certainty of the law based on the UU.

The theory of law development, if it is connected to the law renewal of cash waqf, the goverment should give the policy to improve the rules of cash waqf law by adjusting with the demands of the times. The wakif who has already given waqf is directed profesionally to LKS-PWU. And then wakif gets the proof of doing cash waqf in the form of waqf pledge and the cash waqf certificate. This proof is used as the tool if there is the dispute in the future. This condition motivate the law institutions of cash waqf (LKS-PWU, BWI, nadzir) to make coordination and to synergy in giving good service for the people for doing cash waqf. Besides, the goverment should make an effort to adjust the law awareness of doing waqf by socializing the rules of cash waqf law to the society, the society leader, govermental officer, and the law enforcers, hence there is the harmony in understanding and implementing cash waqf in the society.

The theory of law development stated by Mochtar Kusumaatmaja, compiled with the theory of legal system by Lawrence M. Friedman, explaines that both of them have the similarity and diffrerence. The similarity is that both theories have the same mission to improve and to renewal the law problems in Indonesia which will effect to the effectivity of law implementation in Indonesia. Both theories are very suitable to be applied for the enforcement of law. Using these theories, the law can be renewed, enforced fairly, completed, and perfected. There are many laws in Indonesia that can not be implemented because of some factors. Those factors are; they contradict with Pancasila and with existing of rules, contradict with the available rules in the society or in the religious institutions. Moreover, there are some rules of law that should be changed because they can not be applied in this new era and they can not finish or solve the law problems in the society. If those things are being ignored, the society will become absurd and unobedient. Besides, the law can not be enforced because it can not give the justice for the society.

The difference of those theories is that the legal system theory from Lawrence $\mathrm{M}$. Friedman conceptualizes that the law is one of the unity system which consist of three components, namely; law structure (legal structure), law substantion (legal substantion) and law culture (legal culture). The theory explains that the law enforcement is effected by the law institution, the rules of law and the law culture. Whereas the theory of law renewal from Mochtar Kusumaatmaja views that law is one system consisiting of some subsytems, namely; the principles and rules of law, the law institutions and the process of implementing the law. If those two theories are compared, it explains that the law substantion is likened with the principles and rules of law. The law institutions are used by both theories and the law culture is the process of law implementation in Indonesia.

Substantially, those two theories are the same. The theory of law improvement can use legal system as its theoretical basis, and then it is adapted from the typology of society in Indonesia which believe to the idiotic principle of Pancasila and Constititional of UUD Indonesia Republic Nation 1945. 


\section{Conclusions}

The renewal law of cash waqf is an effort to check or critisize the existing rules of cash waqf and examine its implementation in the society. The implementation of cash waqf law creates the law problems in the society. Those problems are misunderstanding of the society in interpreting cash waqf that cause the interest of the people low to do waqf, there is less coordination among waqf institutions, the cash waqf legality does not fulfilled in LKS-PWU, less attention of the goverment in socializing the cash waqf in the society. Those law problems make the renewal law very important to be done. The law renewal of cash waqf based on the theory approach of legal system; namely; legal structure includes; LKS-PWU need to do the strategy of open access, develope the belief of the people to do cash waqf in LKS-PWU, form professional BWI with profesional managemant, build coordination and synergy cooperation between BWI and LKS-PWU and nadzir who is exist in Indonesia. Legal substantion includes the making of rules which explains that LKS-PWU has a role as nadzir too in managing cash waqf. LKS-PWU had better perfect application form of cash waqf whose has signature column for the witness and nadzir because they are important elements that should be existed in cash waqf. Legal structure consisit of socialization rules of the law, the law education of cash waqf, seminar, workshop, training and empowerment law of cash waqf implementation in the society for the society, academics, practitioner, and some stackholder of cash waqf.

The suggestion is that the law renewal of cash waqf is very urgent to be done in order to build the enforcement of waqf law and to implement the harmony between the national rule and religious institution therefore the society can do cash waqf well and correctly.

Acknowlegdments. This research was supported by Faculty of Law Diponegoro University. We thank our colleagues from private law of Faculty of Law Diponegoro University and colleagues of The Doctoral Program in Law Diponegoro University who provided insight and expertise that greatly assisted the research.

\section{References}

[1] M. Nur Rianto Al Arif, "Efek Multiplier Wakaf Uang Dan Pengaruhnya Terhadap Program Pengentasan Kemiskinan," Asy-Syir'ah, J. Ilmu Syari'ah dan Huk. UIN Syarif Hidayatullah Jakarta, vol. 46, no. 1, pp. 311-312, (2012).

[2] A. A. Setiawan, "Wakaf Uang untuk Pemberdayaan dan Kesejahteran Ummat," Majalah Hidayatullah Edisi 06/XVIII, p. 51, Oct-(2004).

[3] A. Djunaidi, Strategi Pengembangan Wakaf Tunai di Indonesia. Jakarta: Direktorat Pemberdayaan Zakat Departemen Agama RI, (2007).

[4] H. D. L. Toruan, "Penyelesaian Sengketa Hak Kekayaan Intelektual Melalui Acara Cepat Resolution of Intellectual Property Disputes by Fast Proceeding)," J. Penelit. Huk. JURE, vol. 17, no. 1, p. 76, (2107).

[5] Aam S. Rusdiana and Abrista Devi, "Analisis Pengelolaan Dana Wakaf Uang Di Indonesia: Pendekatan Metode Analytic Network Process (ANP)," J. Al-Awqaf (Wakaf dan Ekon. Islam. Badan Wakaf Indones. Jakarta, vol. 10, no. 2, p. 131, (2017).

[6] Suhairi, "Pengelolaan Wakaf Uang (Studi Terhadap Implementasi Wakaf Uang di Baitulmaal Muamalat)," J. Penelit. Keislam. Inst. Agama Islam Negeri Mataram, vol. 7, no. 2, p. 451, (2011).

[7] Hafsah, "Wakaf Produktif Dalam Hukum Islam Indonesia; Analisis Filosofis UU No. 
41/2004 Tentang Wakaf," J. Miqot, vol. XXXIII, no. 1, p. 87, (2009).

[8] T. Prasetyo, Pembaharuan Hukum Dalam Perspektif Teori Keadilan Bermartabat. Malang: Setara Press, (2017).

[9] W. Setiati, "Penegakan Hukum; Kontribusinya Bagi Pendidikan Hukum Dalam Rangka Pengembangan Sumber Daya Manusia (SDM)," J. Maj. Huk. Nas., vol. 2, no. 1, (2018).

[10] L. M. Friedman, The Legal System A Sosial Science Perspektive. New York: Russel Sage Foundation, (1975).

[11] M. U, "Three Patterns of Law: Taxonomy andChange in The World's Legal Systems," Am. J. Comperative Law, vol. 4, no. 5, p. 44, (1997).

[12] E. Warassih, "Optimalisasi Peran Masyarakat Dalam Pengembangan Perbankan Syariah Melalui Budaya Hukum, Makalah Seminar Nasional "Penegakkan Hukum Perbankan Syari'ah Berbasis Syariah"," Semarang, (2012).

[13] W. Friedmen, Law in Changing Society. Penguin Books, (1964).

[14] M. Kusumaatmaja, Hukum, Masyarakat, dan Pembinaan Hukum Nasional. Bandung: Bina Cipta, (1976).

[15] B. A. Sidharta, Refleksi Tentang Struktur Ilmu Hukum. Bandung: Mandar Maju, (2017). 